\title{
PENINGKATAN KUALITAS GURU SMP DI KABUPATEN KEDIRI DALAM PENYUSUNAN SOAL AKM MELALUI PENDAMPINGAN INTENSIF
}

\author{
Sediono $^{1}$, M. Fariz Fadillah Mardianto ${ }^{2 *}$, Siti Maghfirotul Ulyah ${ }^{3}$, \\ Christopher Andreas ${ }^{4}$, Helda Urbhani Rosa ${ }^{5}$, dan Naufal Ramadhan Al \\ Akhwal Siregar ${ }^{6}$ \\ 1,2,3,4,5,6 Program Studi Statistika, Departemen Matematika, Universitas Airlangga, \\ Surabaya, Indonesia. \\ sediono101@gmail.com ${ }^{1}$, m.fariz.fadillah.m@fst.unair.ac.id*2, \\ maghfirotul.ulyah@fst.unair.ac.id ${ }^{3}$, christopher.andreas-2018@ fst.unair.ac.id ${ }^{4}$, \\ helda.urbhani.rosa-2019@fst.unair.ac.id ${ }^{5}$,naufal.ramadhan.al- \\ 2020@fst.unair.ac.id ${ }^{6}$ \\ *Corresponding Author
}

Received 03 October 2021; revised 17 November 2021; accepted 25 November 2021.

\begin{abstract}
ABSTRAK
Riset yang dilakukan Organization for Economic Cooperation and Development (OECD) pada tahun 2018 menunjukkan bahwa kemampuan literasi dan matematika siswa di Indonesia cukup rendah. Kebijakan Ujian Nasional (UN) sebagai alat ukur evaluasi kualitas pendidikan di Indonesia dinilai perlu dievaluasi. Untuk itu, pemerintah menetapkan kebijakan baru pengganti UN yaitu Asesmen Kompetensi Minimum (AKM) dan survei karakter yang mulai diterapkan tahun 2021. Namun, sebagian besar guru belum memiliki wawasan yang cukup mengenai AKM dan survei karakter. Oleh karena itu, diadakan kegiatan workshop dan pendampingan intensif mengenai peningkatan kompetensi guru dalam memahami dan merancang soal berbasis AKM kategori literasi, numerasi, dan survei karakter. Dalam hal ini, sasaran kegiatan tersebut adalah guru Matematika dan IPA tingkat SMP di Kabupaten Kediri. Lebih lanjut, kemampuan seluruh guru diukur sebelum dan sesudah mengikuti kegiatan. Melalui pengujian hipotesis median dengan uji Wilcoxon pada dua sampel berpasangan, diperoleh kesimpulan bahwa terjadi peningkatan kompetensi yang signifikan pada seluruh peserta kegiatan dalam hal pemahaman, perancangan soal AKM kategori literasi, numerasi, dan survei karakter yang masing - masing meningkat sebesar 1.5; 31.5; 25.5; dan 26.5 poin. Melalui kegiatan ini, diharapkan kompetensi guru bertambah guna mendukung peningkatan kualitas pendidikan di Indonesia yang merupakan target Sustainable Development Goals (SDGs).
\end{abstract}

Kata kunci: asesmen kompetensi minimum, guru SMP, literasi, numerasi, survei karakter. 


\begin{abstract}
Research conducted by the Organization for Economic Cooperation and Development (OECD) in 2018 showed that the literacy and mathematics abilities of students in Indonesia were quite low. In fact, the National Examination (UN) policy as a measuring tool for evaluating the quality of education in Indonesia is considered to be changed. For this reason, the government has set a new policy to replace the National Examination, namely the Minimum Competency Assessment (AKM) and a character survey which will begin to be implemented in 2021. However, most of the teachers do not have sufficient knowledge about AKM and character surveys. Therefore, workshops and intensive mentoring activities were held on improving teacher competence in understanding and designing AKM-based questions for the literacy, numeracy, and character survey categories. In this case, the target of the activity is Mathematics and Science teachers at the junior high school level in Kediri Regency. Furthermore, the ability of all teachers is measured before and after participating in the activity. Through testing the median hypothesis with the Wilcoxon test on two paired samples, it was concluded that there was significant increase competence for all activity participants in terms of understanding, designing AKM questions for the literacy, numeracy, and character survey categories, each of which increased by $1.5 ; 31.5$; 25.5; and 26.5 points. Through this activity, it is hoped that teacher competence will increase in order to support improving the quality of education in Indonesia, which is the target of the Sustainable Development Goals (SDGs).
\end{abstract}

Keywords: minimum competency assessment, junior high school teacher, literacy, numeracy, character survey.

\title{
PENDAHULUAN
}

Programme for International Student Assessment (PISA) merupakan sebuah program yang diinisiasi oleh Organization for Economic Cooperation and Development (OECD) yang rutin melakukan riset mengenai kemampuan siswa dalam Matematika, Sains, dan membaca (OECD, 2020). Riset ini dilakukan tiga tahun sekali sejak tahun 2000 dan mengambil sampel siswa dengan usia 15 tahun di 70 negara dari berbagai belahan dunia (Kemendikbud, 2020). Berdasarkan penilaian PISA, Indonesia merupakan salah satu negara yang menduduki peringkat terendah dalam hal membaca dan menghitung daripada negara lainnya. Hasil penilaian tersebut menunjukkan bahwa pada kategori membaca dan menghitung, Indonesia berada di peringkat 7 terbawah dari 78 negara. Pada kategori IPA, Indonesia menduduki peringkat 9 terbawah. Selain itu, menurut 
OECD, siswa Indonesia hanya mampu mengerjakan soal literasi matematis level satu dan level dua, dari enam tingkatan kemampuan literasi matematis siswa yang dirumuskan oleh PISA (OECD, 2019). Dari hasil riset tersebut jelas bahwa kemampuan literasi dan matematis siswa di Indonesia masih rendah. Padahal, peningkatan kualitas pendidikan merupakan salah satu fokus penting dalam Sustainable Development Goals (SDGs).

Di Indonesia, selama ini salah satu pengukuran kualitas pendidikan adalah melalui pelaksanaan Ujian Nasional (UN). Pelaksanaan UN tersebut bertujuan untuk mengukur pencapaian kompetensi lulusan yang mengacu pada Standar Kompetensi Lulusan (SKL) (Badan Standar Nasional Pendidikan, 2017). Namun, pelaksanaan UN tersebut lebih menekankan penguasaan materi pada setiap mata pelajaran. Padahal, kemampuan bernalar dan berpikir secara kritis sangat dibutuhkan di masa mendatang (Purwanto, 2019). Hal ini mendorong pemerintah kembali membuat kebijakan baru berupa penghapusan Ujian Nasional (UN) dan menggantinya menjadi Asesmen Kompetensi Minimum (AKM). Kebijakan pelaksanaan AKM tersebut dilaksanakan mulai tahun 2021. Sebagaimana yang telah disampaikan oleh Menteri Pendidikan dan Kebudayaan Nadiem Makarim, AKM merupakan asesmen yang mengukur kemampuan minimal yang dibutuhkan siswa untuk dapat belajar dan merupakan bentuk penyederhanaan dari Ujian Nasional yang begitu kompleks (Nugraheny, 2019). Adapun materinya terdiri atas tiga komponen yaitu bahasa (literasi), matematika (numerasi), dan pendidikan karakter (Puspendik, 2020).

AKM dilaksanakan dan diterapkan pada jenjang Sekolah Dasar (SD), Sekolah Menengah Pertama (SMP), dan Sekolah Menengah Atas (SMA) di Indonesia, termasuk SMP di Kabupaten Kediri pada bulan September 2021. Namun, berdasarkan komunikasi dengan Kepala Bidang Pendidikan Dasar Dinas Pendidikan Kabupaten Kediri pada 17 Februari 2021, diperoleh fakta yang menunjukkan bahwa guru SMP di Kabupaten Kediri masih belum memiliki pengalaman untuk menerapkan AKM. Hal tersebut logis karena semua guru belum pernah melaksanakan evaluasi berbasis AKM dan survei karakter untuk siswanya. Padahal, saat ini untuk meningkatkan kemampuan literasi, numerasi, dan mengetahui karakter siswa, guru sebagai pengajar dan pendidik perlu 
menyesuaikan sistem pembelajaran di kelas dan menstimulasi siswa untuk meningkatkan kemampuan membaca dan menghitung yang merupakan ranah penilaian menggunakan AKM. Di sisi lain, guru juga berperan penting sebagai fasilitator penguatan pendidikan karakter siswa, seperti jujur, disiplin, taat pada tata tertib, dan lain - lain selama proses belajar mengajar (Agung, 2017). Sebagai contoh, seperti saat melakukan pembelajaran di kelas, siswa diberikan lebih banyak pengalaman dalam menyelesaikan masalah sehari-hari dan diberikan soal yang tidak hanya menggunakan perhitungan dari rumus, tetapi juga menggunakan logika untuk menerjemahkan soal tersebut ke kalimat matematika dalam menyelesaikannya (Handayu, 2020).

Oleh sebab itu, diperlukan workshop dan pendampingan intensif guru guna mempersiapkan pembelajaran yang lebih mengedepankan penalaran dan pendidikan karakter. Dalam hal ini, workshop dan pendampingan intensif guru dilakukan di Kabupaten Kediri yang diikuti 52 guru SMP negeri dan swasta Kabupaten Kediri yang terdiri dari 26 guru Matematika dan 26 guru IPA. Adapun distribusi peserta jika dilihat dari status kepemilikan sekolahnya adalah 27 guru berasal dari SMP negeri dan 25 guru berasal dari SMP swasta. Hal tersebut, telah sesuai dengan proporsi jumlah sekolah SMP Negeri sebanyak 52 sekolah dan jumlah sekolah SMP swasta sebanyak 47 sekolah (Badan Pusat Statistik Kabupaten Kediri, 2021). Dengan adanya pelaksanaan workshop dan pendampingan intensif, guru dapat lebih siap dalam menerapkan pembelajaran yang sesuai dengan sistem AKM. Penelitian ini bertujuan untuk mengukur peningkatan kompetensi guru setelah diberikan kegiatan workshop dan pendampingan intensif dalam merancang soal AKM dan survei karakter. Analisis peningkatan kompetensi guru setelah mengikuti kegiatan workshop dan pendampingan intensif dalam hal pemahaman, perancangan soal AKM kategori literasi, numerasi, dan survei karakter menjadi kebaharuan penelitian ini (Ulyah et al., 2021). Hal ini penting dilakukan untuk memetakan kemampuan guru secara spesifik yang terkait dengan aspek AKM, sehingga evaluasi lebih mudah dilakukan tiap aspek. Melalui penelitian ini, diharapkan kompetensi guru terkait pemahaman dan pembuatan soal AKM kategori literasi, numerasi, dan survei karakter dapat bertambah sehingga mendukung peningkatan kualitas pendidikan 
di Indonesia. Selain itu, guru dapat berinovasi dalam hal pengembangan metode dan media pembelajaran yang adaptif terhadap sistem AKM (Prayitno \& Mardianto, 2020).

\section{METODE PENELITIAN}

Penelitian ini merupakan penelitian kuantitatif yang menekankan pada analisis deskriptif dan pengujian hipotesis Statistika. Penelitian kuantitatif bertujuan untuk mengukur dengan melakukan generalisasi dari hasil sampel ke populasi (Suliyanto, 2017). Analisis statistik deskriptif merupakan teknik analisis data untuk menjelaskan data secara umum atau generalisasi, dengan menghitung nilai minimum, nilai maksimum, rata-rata, dan standar deviasi (Sugiyono, 2017). Uji hipotesis merupakan prosedur penarikan kesimpulan mengenai suatu populasi berdasarkan data yang diperoleh dari suatu sampel. Dalam hal ini, uji hipotesis yang digunakan adalah uji Wilcoxon. Pengujian Wilcoxon merupakan pengujian hipotesis rata - rata untuk dua kelompok sampel yang saling dependen secara nonparametrik yang dapat dilakukan pada data yang tidak berdistribusi normal (Suliyanto, 2014). Pengujian ini merupakan alternatif dari pengujian hipotesis $\mathrm{T}$ untuk dua sampel berpasangan apabila asumsi normalitas data tidak terpenuhi (Walpole, et. al., 2011).

Data dalam penelitian ini merupakan data primer yang diperoleh pada saat kegiatan workshop dan pendampingan intensif. Peserta workshop sebanyak 52 guru SMP di Kabupaten Kediri sebagai objek penelitian. Ada empat variabel yang diukur dalam penelitian ini, yaitu sebagai berikut:

1. Kemampuan dalam memahami soal berbasis AKM.

2. Kemampuan dalam merancang soal AKM kategori literasi.

3. Kemampuan dalam merancang soal AKM kategori numerasi.

4. Kemampuan dalam merancang soal AKM kategori survei karakter.

Data kemampuan dalam memahami soal berbasis AKM merupakan nilai hasil pre-test dan post-test yang dilaksanakan ketika workshop berlangsung pada tanggal 31 Juli 2021. Sedangkan, data kemampuan dalam merancang soal AKM merupakan nilai hasil pembuatan soal AKM kategori literasi, numerasi, dan survei karakter yang dilakukan pada tanggal 31 Juli 2021 (sebelum pendampingan 
intensif) dan tanggal 31 Agustus 2021 (setelah pendampingan intensif). Dalam merancang soal AKM kategori literasi, numerasi, dan survei karakter, dilakukan pendampingan intensif dengan cara membentuk kelompok kecil yang terdiri dari 5-6 guru dimana setiap kelompok dipandu oleh seorang pendamping dan asisten pendamping yang selalu mengontrol kemampuan guru dalam merancang soal AKM.

Secara rinci, prosedur penelitian sebagai berikut:

1. Pembuatan instrumen penelitian yang meliputi soal pre-test, post-test, dan perancangan soal AKM kategori literasi, numerasi, dan survei karakter sebelum kegiatan workshop dan pendampingan intensif.

2. Pengumpulan data yang dilakukan ketika workshop berlangsung, serta di awal dan akhir kegiatan pendampingan intensif.

3. Analisis data yang dilakukan secara deskriptif dan inferensi melalui pengujian hipotesis dengan uji Wilcoxon pada tingkat kesalahan 5\%.

4. Menarik kesimpulan dan memberi rekomendasi berdasarkan hasil analisis yang dilakukan.

\section{HASIL PENELITIAN DAN PEMBAHASAN}

Setelah dilakukan workshop dan pendampingan intensif penyusunan soal AKM, selanjutnya dilakukan analisis terkait kompetensi guru sebelum dan sesudah mengikuti kegiatan. Dalam hal ini, setiap guru dipandu untuk memahami dan merancang soal - soal literasi, numerasi, dan survei karakter yang sesuai standar AKM.

\section{Kemampuan dalam Memahami Soal Berbasis AKM}

Pada pelaksanaan workshop diadakan dua jenis tes untuk mengetahui tingkat pemahaman peserta terkait soal berbasis AKM yaitu pre-test dan post-test. Pre-test dilaksanakan sebelum pemaparan materi untuk mengetahui pemahaman awal peserta dan post-test dilaksanakan sesudah pemaparan materi. Berdasarkan nilai yang diperoleh dari kedua jenis tes tersebut, dilakukan pengujian apakah terdapat peningkatan pemahaman yang signifikan terkait kemampuan peserta dalam memahami soal berbasis AKM melalui uji Wilcoxon dengan hipotesis sebagai berikut: 
$\mathrm{H}_{0}$ : Tidak terdapat perbedaan median nilai pre-test dan post-test.

$\mathrm{H}_{1}$ : Terdapat perbedaan median nilai pre-test dan post-test.

Selanjutnya, dilakukan uji Wilcoxon dengan hasil yang disajikan pada Tabel 1.

Tabel 1. Ringkasan Hasil Uji Wilcoxon untuk Pemahaman AKM

\begin{tabular}{lcccc}
\hline & $\mathrm{Z}$ & P-value & Keputusan & Keterangan \\
\hline $\begin{array}{l}\text { Nilai tes sebelum dan } \\
\text { sesudah mengikuti workshop }\end{array}$ & -4.437 & 0.000 & ${\text { Tolak } \mathrm{H}_{0}}$ & Signifikan \\
\hline
\end{tabular}

Berdasarkan Tabel 1, pengujian Wilcoxon menunjukkan hasil yang signifikan untuk perbedaan median pada nilai pre-test dan post-test peserta sebelum dan sesudah mengikuti workshop. Lebih lanjut, deskripsi nilai pre-test dan post-test disajikan pada Tabel 2. Berdasarkan Tabel 2, terlihat bahwa rata rata dan median nilai post-test mengalami peningkatan dibandingkan nilai pretest. Hal ini menunjukkan bahwa workshop yang dilaksanakan berhasil membantu meningkatkan pemahaman peserta terkait soal berbasis AKM.

Tabel 2. Statistik Deskriptif Nilai Pre-test dan Post-test untuk Pemahaman AKM

\begin{tabular}{cccccc}
\hline Variabel & N & Mean & Median & Minimum & Maksimum \\
\hline Pre-test & 52 & 64.31 & 58.50 & 50 & 95 \\
Post-test & 52 & 77.88 & 60.00 & 60 & 95 \\
\hline
\end{tabular}

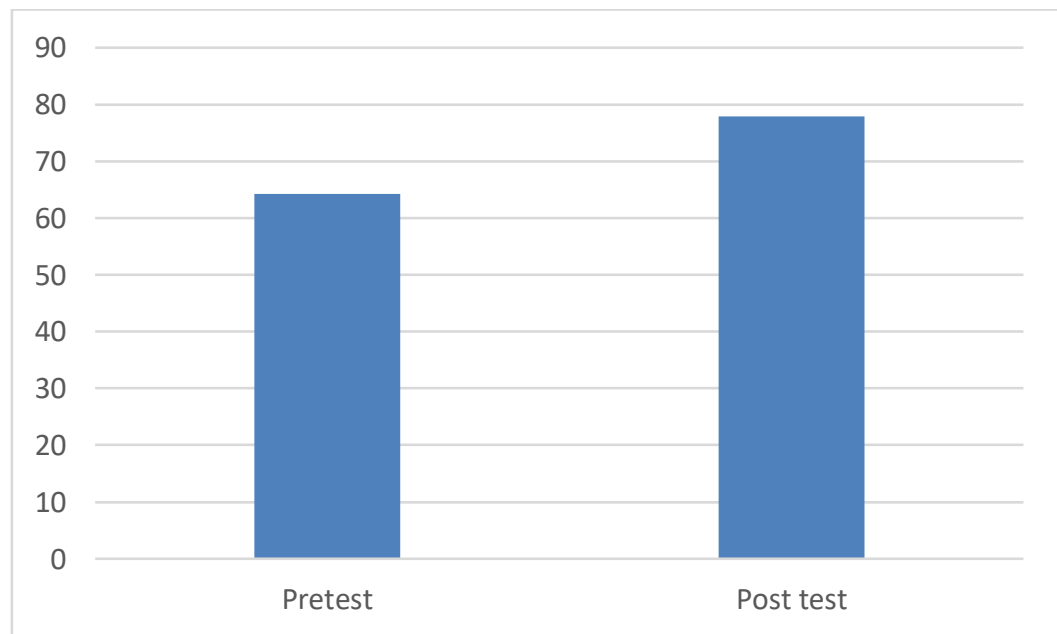

Gambar 1. Rata-Rata Nilai Pre-test dan Post-test untuk Pemahaman AKM 
Gambaran lebih lanjut terkait peningkatan rata - rata nilai post-test dibandingkan nilai pre-test divisualisasikan pada Gambar 1. Berdasakan Gambar 1 dan hasil uji Wilcoxon terlihat adanya peningkatan yang signifikan pada rata rata nilai pre-test yang awalnya 64.31 menjadi 77.88 pada nilai post-test, yaitu sebesar 13.57 poin.

\section{Kemampuan dalam Merancang Soal AKM Kategori Literasi}

Dalam tahap ini guru diberikan penugasan untuk merancang soal AKM kategori literasi dengan frekuensi tugas sebanyak dua kali. Pada penugasan pertama peserta diminta untuk mencari referensi artikel dan merancang soal AKM kategori literasi sebelum diberi pendampingan intensif. Pada penugasan kedua peserta diminta merancang soal AKM kategori literasi setelah adanya pendampingan intensif oleh dosen dan mahasiswa. Oleh karena itu, dilakukan pengujian untuk mengetahui apakah terdapat peningkatan kemampuan guru secara signifikan dalam merancang soal AKM kategori literasi sebelum dan setelah mengikuti pendampingan intensif melalui uji Wilcoxon dengan hipotesis sebagai berikut:

$\mathrm{H}_{0}$ : Tidak terdapat perbedaan median nilai peserta dalam membuat soal AKM literasi sebelum dan sesudah mengikuti pendampingan intensif

$\mathrm{H}_{1}$ : Terdapat perbedaan median nilai peserta dalam membuat soal AKM literasi sebelum dan sesudah mengikuti pendampingan intensif Selanjutnya, dilakukan uji Wilcoxon dengan hasil yang disajikan pada Tabel 3.

Tabel 3. Ringkasan Hasil Uji Wilcoxon untuk Perancangan Soal AKM Literasi

\begin{tabular}{lcccc}
\hline & $\mathrm{Z}$ & $P$-value & Keputusan & Keterangan \\
\hline $\begin{array}{l}\text { Nilai soal AKM literasi } \\
\text { sebelum dan sesudah }\end{array}$ & -6.084 & 0.000 & Tolak $\mathrm{H}_{0}$ & Signifikan \\
\begin{tabular}{l} 
mengikuti pendampingan \\
\hline
\end{tabular} & & & & \\
\hline
\end{tabular}

Berdasarkan Tabel 3, uji Wilcoxon menunjukkan hasil yang signifikan untuk perbedaan nilai median dalam merancang soal AKM literasi sebelum dan sesudah mengikuti pendampingan intensif. Selain itu, statistika deskriptif untuk nilai perancangan soal AKM literasi sebelum dan sesudah mengikuti 
pendampingan intensif disajikan pada Tabel 4. Berdasarkan Tabel 4, terlihat bahwa terjadi peningkatan nilai mean dan median setelah mengikuti pendampingan intensif. Hal ini menunjukkan bahwa pendampingan intensif berhasil membantu meningkatkan kemampuan peserta dalam menyusun soal literasi yang sesuai standar AKM.

Tabel 4. Statistik Deskriptif Nilai Soal AKM Literasi

\begin{tabular}{cccccc}
\hline Variabel & N & Mean & Median & Minimum & Maksimum \\
\hline Literasi1 & 52 & 51.73 & 53.50 & 20 & 86 \\
Literasi2 & 52 & 82.23 & 85.00 & 50 & 94 \\
\hline
\end{tabular}

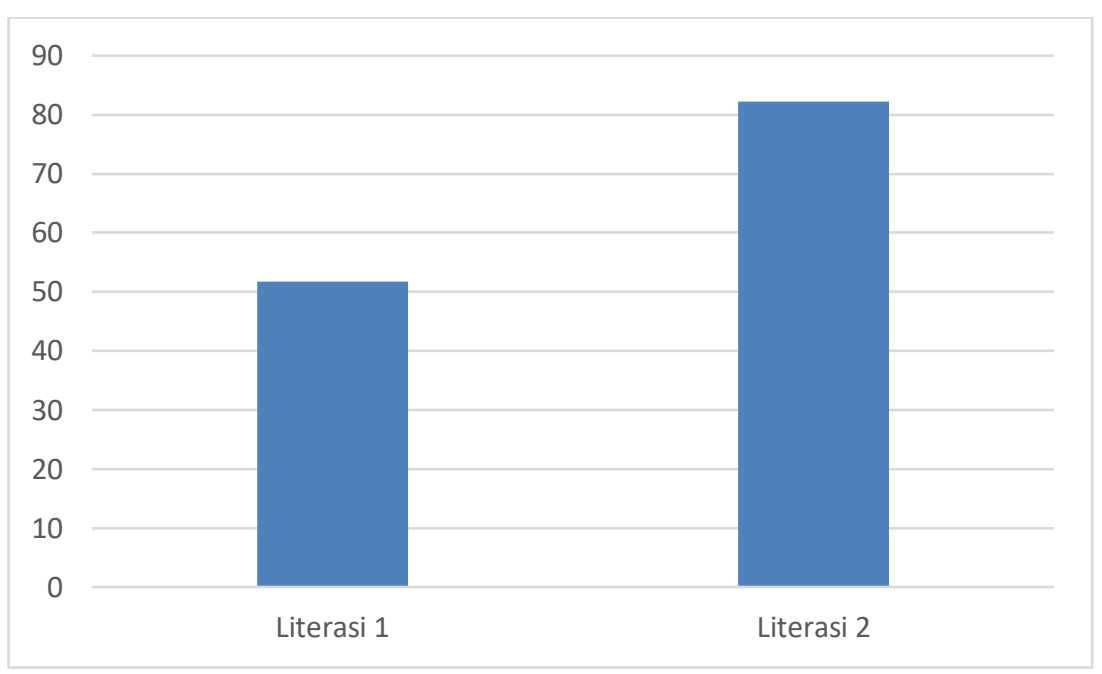

Gambar 2. Rata-Rata Nilai Merancang Soal AKM Literasi

Gambaran lebih lanjut terkait peningkatan rata - rata nilai perancangan soal AKM literasi divisualisasikan pada Gambar 2. Berdasakan Gambar 2 dan hasil uji Wilcoxon terlihat adanya peningkatan yang signifikan pada rata - rata nilai sebelum diadakan pendampingan intensif yang awalnya 51.73 menjadi 82.23 setelah diadakan pendampingan intensif, yaitu sebesar 30.5 poin.

\section{Kemampuan dalam Merancang Soal AKM Kategori Numerasi}

Pada tahap ini guru diberikan penugasan untuk merancang soal AKM kategori numerasi dengan frekuensi tugas sebanyak dua kali. Pada penugasan pertama peserta diminta untuk merancang soal AKM kategori numerasi sebelum pendampingan intensif. Sedangkan, pada penugasan kedua peserta diminta untuk 
merancang soal AKM kategori numerasi setelah diberikan pendampingan intensif selama satu bulan. Oleh karena itu, dilakukan pengujian untuk mengetahui apakah terdapat peningkatan kemampuan guru secara signifikan dalam merancang soal AKM kategori numerasi sebelum dan sesudah mengikuti pendampingan intensif melalui pengujian Wilcoxon. Hipotesis yang digunakan adalah sebagai berikut:

$\mathrm{H}_{0}$ : Tidak terdapat perbedaan median nilai peserta dalam membuat soal AKM numerasi sebelum dan sesudah mengikuti pendampingan intensif

$\mathrm{H}_{1}$ : Terdapat perbedaan median nilai peserta dalam membuat soal AKM numerasi sebelum dan sesudah mengikuti pendampingan intensif Selanjutnya, dilakukan uji Wilcoxon dengan hasil yang disajikan pada Tabel 5.

Tabel 5. Ringkasan Hasil Uji Wilcoxon untuk Perancangan Soal AKM Numerasi

\begin{tabular}{lcccc}
\hline & $\mathrm{Z}$ & $P$-value & Keputusan & Keterangan \\
\hline $\begin{array}{l}\text { Nilai soal AKM numerasi } \\
\text { sebelum dan sesudah }\end{array}$ & -6.094 & 0.000 & ${\text { Tolak } \mathrm{H}_{0}}^{\text {Signifikan }}$ & Sikut pendampingan \\
mengikuti pending & & & & \\
\hline
\end{tabular}

Berdasarkan Tabel 5, hasil pengujian Wilcoxon menunjukkan hasil yang signifikan untuk perbedaan nilai median dalam merancang soal AKM numerasi sebelum dan sesudah mengikuti pendampingan intensif. Selanjutnya, nilai perancangan soal AKM numerasi sebelum dan sesudah mengikuti pendampingan diringkas pada Tabel 6. Berdasarkan Tabel 6, median nilai peserta sebelum mengikuti pendampingan intensif dan sesudah mengikuti pendampingan intensif mengalami peningkatan sebesar 25.50. Selain itu, nilai mean juga mengalami peningkatan sebesar 31.50. Hal ini menunjukkan bahwa pendampingan intensif yang dilaksanakan berhasil membantu meningkatkan kemampuan peserta dalam merancang soal numerasi yang sesuai standar AKM.

Tabel 6. Statistik Deskriptif Nilai Soal AKM Numerasi

\begin{tabular}{cccccc}
\hline Variabel & N & Mean & Median & Minimum & Maksimum \\
\hline Numerasi1 & 52 & 58.73 & 60.50 & 12 & 95 \\
Numerasi2 & 52 & 85.46 & 86.00 & 65 & 94 \\
\hline
\end{tabular}




\section{Peningkatan Kualitas Guru SMP di Kabupaten Kediri dalam Penyusunan Soal AKM melalui Pendampingan Intensif}

Gambaran lebih lanjut terkait peningkatan rata - rata nilai perancangan soal AKM numerasi divisualisasikan pada Gambar 3. Berdasakan Gambar 3 dan hasil uji Wilcoxon terlihat adanya peningkatan yang signifikan pada rata - rata nilai sebelum diadakan pendampingan intensif yang awalnya 58.73 menjadi 85.46 setelah diadakan pendampingan intensif, yaitu sebesar 26.73 poin.

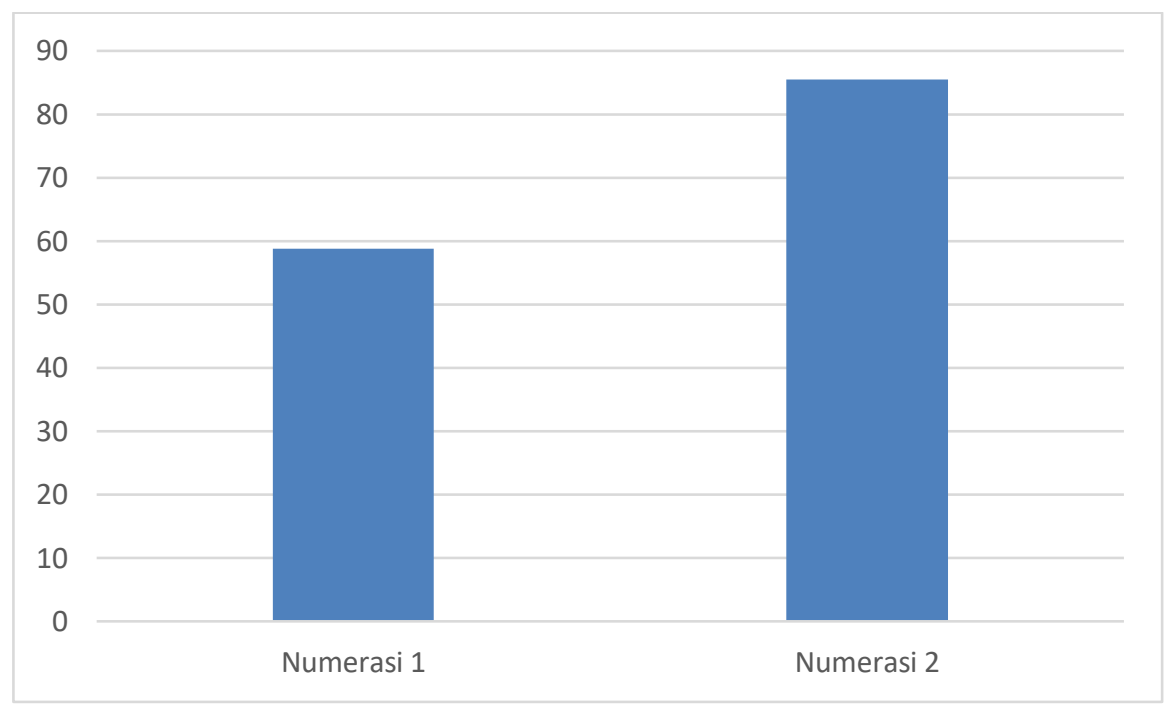

Gambar 3. Rata-Rata Nilai Merancang Soal AKM Numerasi

\section{Kemampuan dalam Merancang Soal AKM Kategori Survei Karakter}

Dalam tahap ini, guru diberikan penugasan untuk merancang soal AKM kategori survei karakter dengan frekuensi tugas sebanyak dua kali. Pada penugasan pertama peserta diminta untuk mengumpulkan soal AKM kategori survei karakter yang telah dipersiapkan sebelum diberikan pendampingan intensif. Pada penugasan kedua peserta diminta merancang soal AKM kategori survei karakter setelah pendampingan intensif yang didampingi oleh dosen dan mahasiswa selama satu bulan. Dengan demikian, dilakukan uji hipotesis Wilcoxon untuk mengetahui apakah terdapat peningkatan signifikan pada kemampuan guru dalam merancang soal AKM kategori survei karakter setelah mengikuti pendampingan intensif dengan hipotesis yang diuji sebagai berikut.

$\mathrm{H}_{0}$ : Tidak terdapat perbedaan median nilai peserta dalam membuat soal survei karakter sebelum dan sesudah mengikuti pendampingan intensif 
$\mathrm{H}_{1}$ : Terdapat perbedaan median nilai peserta dalam membuat soal survei karakter sebelum dan sesudah mengikuti pendampingan intensif

Selanjutnya, dilakukan uji Wilcoxon dengan hasil yang disajikan pada Tabel 7.

Tabel 7. Ringkasan Hasil Uji Wilcoxon Perancangan Soal AKM Survei Karakter

\begin{tabular}{lcccc}
\hline & $\mathrm{Z}$ & $P$-value & Keputusan & Keterangan \\
\hline $\begin{array}{l}\text { Nilai soal survei karakter } \\
\text { sebelum dan sesudah } \\
\text { mengikuti pendampingan }\end{array}$ & -5.757 & 0.000 & Tolak $\mathrm{H}_{0}$ & Signifikan \\
\hline
\end{tabular}

Berdasarkan Tabel 7, uji Wilcoxon menunjukkan hasil yang signifikan untuk perbedaan nilai median dalam merancang soal survei karakter sebelum dan sesudah mengikuti pendampingan intensif. Lebih lanjut, deskripsi data nilai disajikan pada Tabel 8. Mean dan median data mengalami peningkatan setelah mengikuti pendampingan intensif seperti yang ditunjukkan pada Tabel 8. Hal ini menunjukkan bahwa pendampingan intensif berhasil meningkatkan kemampuan peserta dalam menyusun soal survei karakter yang sesuai standar AKM.

Tabel 8. Statistik Deskriptif Nilai Soal Survei Karakter

\begin{tabular}{cccccc}
\hline Variabel & N & Mean & Median & Minimum & Maksimum \\
\hline Survei Karakter 1 & 52 & 53.79 & 52.00 & 15 & 90 \\
Survei Karakter 2 & 52 & 77.67 & 78.50 & 50 & 95 \\
\hline
\end{tabular}

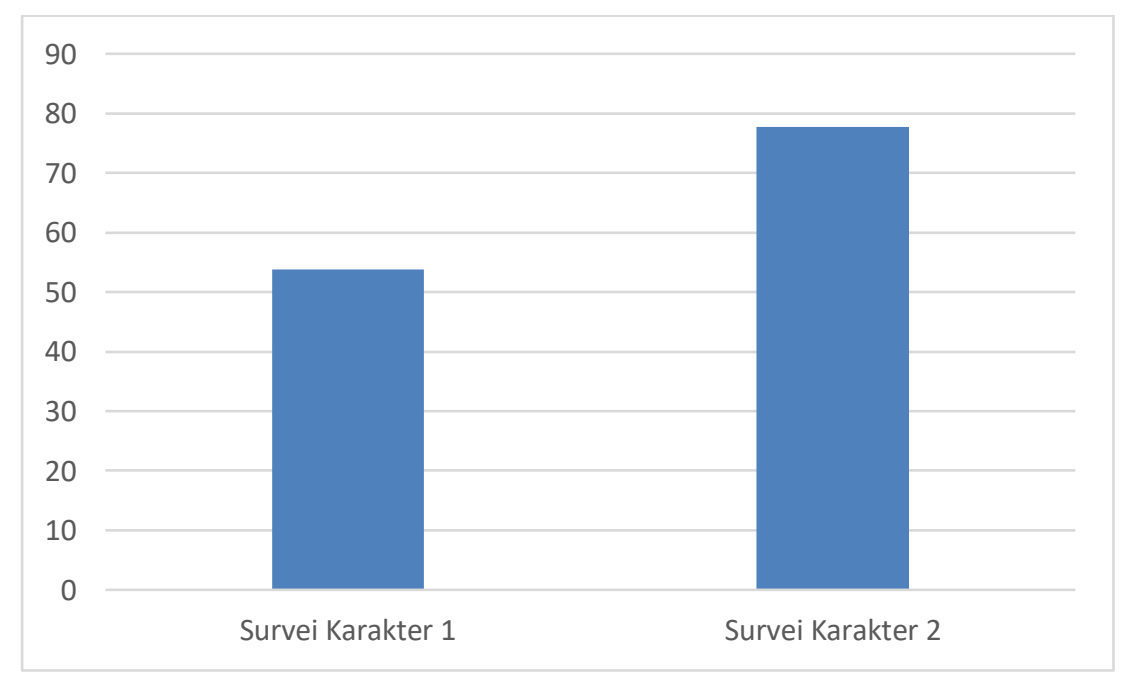

Gambar 4. Rata-Rata Nilai Merancang Soal Survei Karakter. 


\section{Peningkatan Kualitas Guru SMP di Kabupaten Kediri dalam Penyusunan Soal AKM melalui Pendampingan Intensif}

Gambaran lebih lanjut terkait peningkatan rata - rata nilai perancangan soal survei karakter divisualisasikan pada Gambar 4. Berdasakan Gambar 4 dan hasil uji Wilcoxon terlihat adanya peningkatan yang signifikan pada rata - rata nilai sebelum diadakan pendampingan intensif yang awalnya 53.79 menjadi 77.67 setelah diadakan pendampingan intensif, yaitu sebesar 23.88 poin.

Secara keseluruhan, hasil penelitian ini memperkuat hasil dari penelitian Ulyah et al. (2021) yang menunjukkan bahwa pemberian workshop dapat meningkatkan kompetensi guru terkait AKM. Namun demikian, penelitian ini memberikan perbedaan analisis dengan Ulyah et al. (2021), dimana penelitian sebelumnya hanya menunjukkan peningkatan kompetensi guru secara keseluruhan. Dalam penelitian ini, peningkatan kompetensi guru ditinjau dari setiap aspek yaitu kemampuan dalam memahami soal AKM, kemampuan dalam merancang soal AKM kategori literasi, kemampuan dalam merancang soal AKM kategori numerasi, dan kemampuan dalam merancang soal AKM kategori survei karakter.

\section{SIMPULAN}

Workshop dan pendampingan intensif terkait pemahaman soal AKM, perancangan soal literasi, numerasi, dan survei karakter ini diadakan untuk memberikan wawasan pada guru Matematika dan IPA jenjang SMP di Kabupaten Kediri agar lebih memahami, khususnya terkait pembuatan soal yang sesuai standar AKM. Hasil penelitian menunjukkan bahwa kompetensi guru mengalami peningkatan yang signifikan setelah mengikuti kegiatan workshop dan pendampingan intensif selama satu bulan. Peningkatan kompetensi tersebut terdiri dari aspek pemahaman, perancangan soal AKM kategori literasi, numerasi, dan survei karakter yang ditandai dengan peningkatan median nilai masing - masing sebesar 1.5; 31.5; 25.5; dan 26.5 poin. Dengan demikian, tujuan dari kegiatan tersebut telah tercapai karena telah terjadi peningkatan kompetensi guru dalam pemahaman dan perancangan soal AKM. Atas dasar keberhasilan tersebut, kegiatan ini dapat diterapkan dengan sasaran guru bidang studi lainnya atau guru 
jenjang pendidikan lain didalam maupun diluar Kabupaten Kediri sehingga diharapkan mampu mendukung peningkatan kualitas pendidikan di Indonesia.

\section{UCAPAN TERIMA KASIH}

Penulis mengucapkan terima kasih kepada Lembaga Penelitian dan Pengabdian Masyarakat Universitas Airlangga (LPPM UNAIR) yang telah memberikan pendanaan. Selain itu, penulis juga mengucapkan terima kasih kepada Dinas Pendidikan Kabupaten Kediri yang telah memberikan dukungan informasi dan perizinan observasi.

\section{DAFTAR PUSTAKA}

Agung, I. (2017). Peran Fasilitator Guru dalam Penguatan Pendidikan Karakter (PPK). Perspektif Ilmu Pendidikan, 31(2), 106 - 119.

Badan Pusat Statistik Kabupaten Kediri. (2021). Kabupaten Kediri dalam Angka 2021. Kediri: BPS Kediri.

Badan Standar Nasional Pendidikan. (2017). Buku Saku UN. Diakses pada 28 September 2021, dari https://bsnp-indonesia.org.

Handayu, A. R. (2020). Analisis Terhadap Butir Soal Asesmen Kompetensi Minimum (AKM) Tingkat SMP Ditinjau Dari Domain Literasi Matematis Pisa. Bandung: Thesis Universitas Pendidikan Indonesia.

Kemendikbud. (2020). Programme for International Student Assessment (PISA). Diakses pada 29 September 2021, dari https://litbang.kemdikbud.go.id/pisa.

Nugraheny, D. E. (2019). Selengkapnya, Ini Program Nadiem Makarim yang Akan Gantikan UN. Diakses pada 29 September 2021, dari https://nasional.kompas.com/read/2019/12/12/06584211/selengkapnya-iniprogram-nadiem-makarim-yang-akan-gantikan-un?page=all.

Prayitno, \& Mardianto, M. F. F. (2020). Peningkatan Hasil Evaluasi Pembelajaran Daring saat Pandemi Covid-19 Berdasarkan Media Powerpoint Interaktif. Journal of Mathematics Education, Science and Technology, 5(2), 171-181.

OECD. (2019). PISA 2018: latest result. Diakses pada 28 September 2021, dari PISA, Programme for International Student Assessment: https://www.oecd.org/pisa/.

OECD. (2020). What is PISA?. Diakses pada 28 September 2021, dari PISA, Programme for International Student Assessment:https://www.oecd.org/pisa/.

Purwanto. (2019). UN Dihapus, Ini Penjelasan Kementerian Pendidikan. Diakses pada 28 September 2021, dari https://nasional.tempo.co/read/1282951/undihapus-ini-penjelasan-kementerian-pendidikan/full\&view=ok.

Puspendik. (2020). Asesmen Kompetensi Minimum (AKM). Diakses pada 28 September 2021, dari https://hasilun.puspendik.kemdikbud.go.id/akm/.

Suliyanto. (2014). Statistika Non Parametrik dalam Aplikasi Penelitian. Yogyakarta: ANDI.

Suliyanto. (2017). Metode Pelatihan Kuantitatif. Journal of Chemical Information and Modeling, 5(2), 223-232. 
Sugiyono, P. D. (2017). Metode Penelitian Bisnis: Pendekatan Kuantitatif, Kualitatif, Kombinasi, dan R\&D. CV Alfabeta: Bandung.

Ulyah, S. M., Sediono, Ana, E., Sholihah, N., \& Niswatin, K. (2021). Improving the Competency of High School Teachers in Understanding and Designing Questions Based on Minimum Competency Assessment in Babat Lamongan District. Journal of Mathematics Education, Science and Technology, 6(1), $55-64$.

Walpole, R. E., Myers, R. H., \& Myers, S. L. (2011). Probability and Statistics for Engineers and Scientists, 9th Edition. Boston: Prentice Hall. 